ZOOLOGIA 28 (3): 357-364, June, 2011

doi: $10.1590 /$ S1984-46702011000300010

\title{
Zooplankton of an urban coastal lagoon: composition and association with environmental factors and summer fish kill
}

\author{
Leonardo C. e Souza ${ }^{1,4}$; Christina W. C. Branco'; Patrícia Domingos² \& Sérgio L. C. Bonecker \\ ${ }^{1}$ Núcleo de Estudos Limnológicos, Departamento de Zoologia, Instituto de Biociências, Universidade Federal do Estado do \\ Rio de Janeiro. Avenida Pasteur 458, Urca, 22290-050 Rio de Janeiro, RJ, Brazil. \\ ${ }_{2}^{2}$ Instituto Estadual de Ambiente, Gerência de Qualidade de Águas, Diretoria de Informação e Monitoramento. Avenida \\ Venezuela 110, Centro, 20081-312, Rio de Janeiro, RJ, Brazil. \\ ${ }^{3}$ Laboratório de Zooplâncton e Ictioplâncton, Centro de Ciências e Saúde, Universidade Federal do Rio de Janeiro. \\ ${ }^{4}$ Corresponding author. E-mail: coimbra@@hotmail.com
}

\begin{abstract}
Zooplankton may be regarded as a sensitive tool for monitoring environmental variations in coastal lagoons due to their ability to immediately react to changes in the water column trophic features and salinity levels. As a coastal lagoon with a broad history of anthropic influence, Rodrigo de Freitas Lagoon (Rio de Janeiro, Brazil) is widely used for water sports and artisanal fishing. The present study aimed to expand the knowledge base about zooplankton in the Rodrigo de Freitas Lagoon by assessing the composition and time-spatial distribution of the major zooplankton groups. Samples were collected fortnightly from at four distinct sampling points August 2001 to July 2002. At each point, salinity, temperature, dissolved oxygen and water transparency were measured. During the study period, the lagoon behaved as an spatially homogeneous environment in what regards the abiotic variables. However, all these variables showed significant differences along the time, mainly related to seasonality (air temperature and rainy and dry periods). The zooplankton community showed low taxonomic richness, with the predominance of species commonly found in coastal lagoons, especially with mesohaline conditions, as well as those found in estuaries. An interesting fact was the rise in zooplankton abundance at all sampling points right after a fish kill event. Such increase was caused mainly by the Brachionus plicatilis O.F. Müller 1786 species. Thus, the zooplankton community was affected by physical and chemical factors, mainly by the dissolved oxygen decline event and variations in the influx of seawater into the lagoon. In addition, phytoplankton availability and fish predation pressure were suggested as important regulating factors of the zooplankton community.
\end{abstract}

KEY WORDS. Brachionus plicatilis; dissolved oxygen; fish mortality; mesohaline; shallow waters.

Coastal lagoons can be characterized as relatively shallow waters, partially or entirely separated from the sea by sand barriers that are formed as a result of sea waves and tides and which are affected by the input of rivers, the action of the winds, tides, the balance between rain precipitation and evaporation (BARNes 1980, KJERFVE 1994). In Brazil as in many regions of the world, the major problem that affects urban coastal lagoons is eutrophication, a process by which a body of water acquires a high concentration of nutrients from its surrounding areas (BRANCO et al. 2007). In addition to showing high biological productivity, such ecosystems are major repositories of aquatic biodiversity, and this points to the importance of assessing the various natural communities in order to establish a baseline for management and conservation of similar environments, whether the latter are preserved or not.

As a coastal lagoon with a broad history of anthropic influence, Rodrigo de Freitas Lagoon plays a major role in the landscape of the city of Rio de Janeiro, as it is widely used for water sports and artisanal fishing. The concern about fish kill and insect proliferation and suggestions about hydrobiological conditions of the lagoon back in the 1930s and 1950s (Aragão et al. 1939, Oliveira 1955). Recovery studies and projects were implemented by environmental organizations and study centers along the last century to investigate physical and chemical features of this lagoon (FEEMA 2002).

The first study about Rodrigo de Freitas Lagoon's aquatic biota was conducted by Oliveira et al. (1957) and suggested probable causes for fish kill. Several other studies addressed the aquatic communities of the lagoon, especially the nektonic (e.g. Andreata \& Mendonça Neto 2001, Andreata et al. 2002, and Andreata et al. 2004). With respect to plankton communities, Lutterbach et al. (2001) and Gonzalez et al. (2006) investigated the abundance of heterotrophic bacteria and FEEMA (2002) carried out the inventory of phytoplankton focusing on potentially harmful species. Few studies included observations on zooplankton (Oliveira et al. 1957, 1962) but no work has been conducted aiming at characterizing this community in the lagoon. 
Among the invertebrates occurring in lagoon ecosystems, zooplankton plays a significant role as a major link in the local trophic chain for carrying bacteria and phytoplankton energy to other invertebrates and fish. On the other hand, the distribution and the spatial and temporal variation of zooplankton associations seem to be directly related to the features of the water environment.

Given their short life cycles, zooplankton organisms respond promptly to environmental changes and hence, their standing crops and species community composition are clear indicators of the quality of the water bodies where they live (Berzins \& Pejler 1987, Kuczynski 1987, Branco et al. 2000). Thus, zooplankton may be regarded as a very sensitive tool for monitoring environmental variations in coastal lagoons because of their ability to immediately react to changes in the water column, like for instance, changes in trophic features and in salinity levels (BRANCO et al. 2007). Some studies about antrophic impact upon zooplankton in Brazilian coastal lagoons were conducted in the state of Rio de Janeiro (e.g. Arcifa et al. 1994, Attayde \& Bozelli 1998, Branco et al. 2000, 2007, KozlowskySUZUKI \& Bozelli 2002, 2004).

The present study aims to expand the knowledge base about zooplankton in the Rodrigo de Freitas Lagoon by assessing the composition and time-spatial distribution of the major zooplankton groups, as well as taxon-environment relationships and the influence of a summer fish kill.

\section{MATERIAL AND METHODS}

The study was conducted in the Rodrigo de Freitas Lagoon (Fig. 1), one of the major coastal ecosystems in the municipality of Rio de Janeiro, located between latitudes $22^{\circ} 57^{\prime} 02^{\prime \prime}-22^{\circ} 58^{\prime} 09^{\prime \prime} \mathrm{S}$ and longitudes $043^{\circ} 11^{\prime} 09^{\prime \prime}-043^{\circ} 13^{\prime} 03^{\prime \prime} \mathrm{W}$. Having an approximate surface area of $2.2 \mathrm{~km}^{2}$, an average depth of $2.8 \mathrm{~m}$ and a maximum depth of $4.0 \mathrm{~m}$, this lagoon is located in one of the urban areas of the southern coast of the municipality of Rio de Janeiro.

The surroundings of Rodrigo de Freitas Lagoon are composed by hillside streams that drain mostly rock masses ("Inselbergs"), rainforest and residential areas. At the lowest basin areas, the land use is predominantly urban with a high population density. The volume of the main streams increases at high rainfall times, consequently raising the lagoon water level and causing flooding of urban areas (FEEMA 2002). Since the lagoon is surrounded by a highly urbanized area it receives influx of polluted waters from some uncontrolled sewage system and from storm sewer.

Rodrigo de Freitas Lagoon is connected to the sea through the Jardim de Alah canal a completely artificial channel about $800 \mathrm{~m}$ long and with a varying width between $10 \mathrm{~m}$ and $18 \mathrm{~m}$ (FEEMA 2002). Most of the time, the canal mouth is silted as a result of the sedimentary effect of sea circulation. Silting also occurs at the downstream end, at the lagoon-canal intersection,

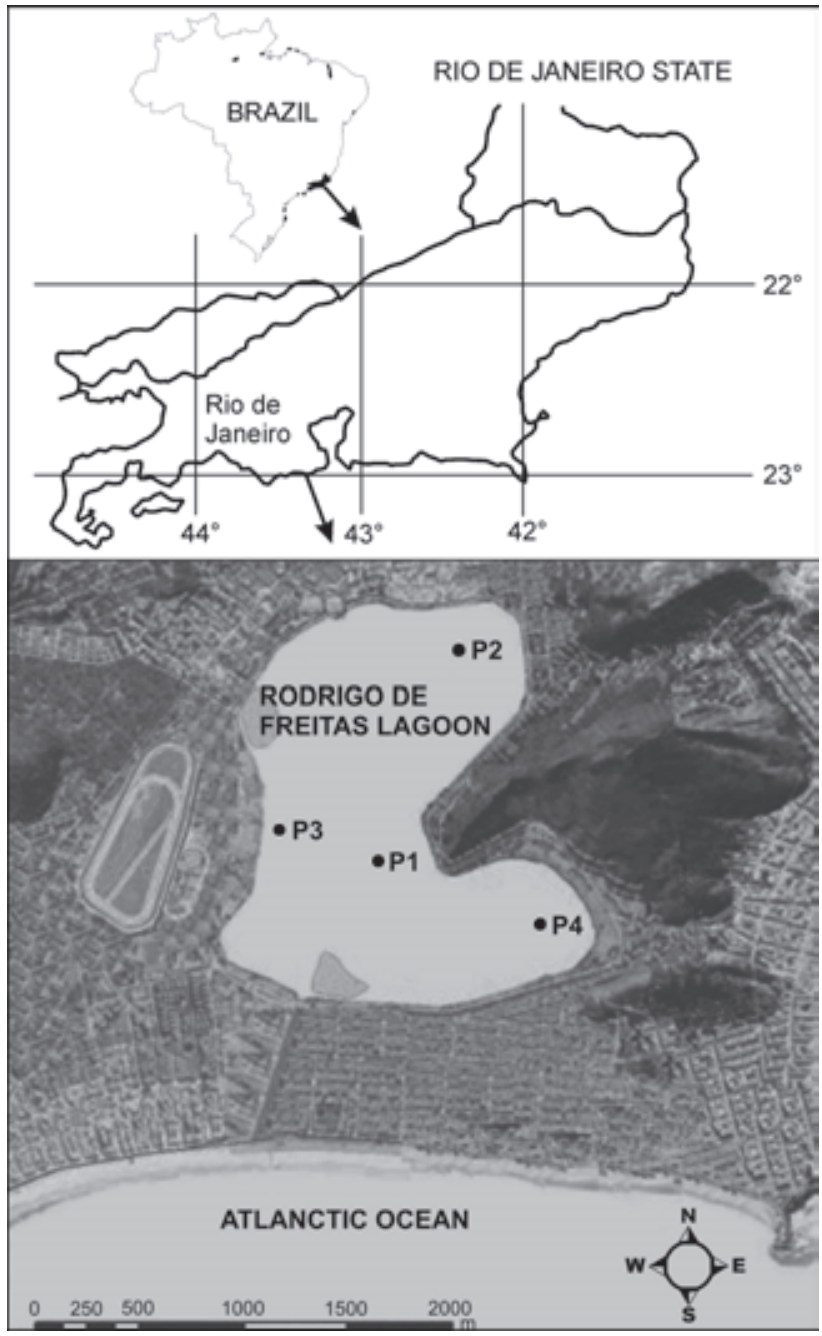

Figure 1. Location of Rodrigo de Freitas Lagoon on the Brazilian coast and and position of sampling points.

which reduces water exchange time and volume. The higher level of the lagoon compared with the sea also makes difficult water changes. The lagoon has a residence time longer than 365 days (FEEMA 2002) and belongs to the category of choked lagoons for having long water residence and little sea water exchange (KJERFVE 1994), features that enhance eutrophication.

Zooplankton sampling was done fortnightly along 12 months (August 2001 through July 2002), at four distinct sampling points (P1, P2, P3 e P4) along Rodrigo de Freitas Lagoon (Fig. 1). Samples were collected by using a $68 \mu \mathrm{m}$ mesh plankton net, by vertical hauls from bottom $(2.5-3.0 \mathrm{~m})$ to surface. Samples were immediately fixed with $4 \%$ buffered formalin. The filtered volume was obtained by calculating $\mathrm{V}=$ h.2. $\pi . \mathrm{r}$; where: $\mathrm{V}=$ sample volume $\mathrm{h}=$ depth distance, $\mathrm{r}=$ the net opening radius distance. 
At each sampling point water transparency measured by a Secchi disk and profiles of water temperature, salinity, and dissolved oxygen (DO) were taken at $5 \mathrm{~m}$ intervals by a multi-parametric probe (Troll 9500). Rainfall data was obtained from the Instituto Nacional de Meteorologia - INMET's (National Meteorology Institute of Brazil) website. Qualitative and quantitative analyses were conducted using an optical microscope Olympus BX51. Sedgewick-Rafter chambers of $1 \mathrm{~mL}$ volume were used in counting and the aliquot was removed from a well-mixed sample using a Hensen-Stempel pipette-type. At least 200 individuals were counted in each of five sequential sub-samples. Nevertheless, the whole sample was inspected for rare species, which were included in the counting. Organisms were separated by species (holoplanktonic rotifers and copepods) or taxonomic groups (meroplanktonic and nectobenthonic forms). Juvenile Calanoid Copepods (copepodites) and adult copepods were placed in one only taxon entitled "Calanoid Copepod" for data treatment purposes, whereas copepod larvae (nauplii), irrespective of the Order they belong to, were treated as a separate taxon entitled "Copepod Nauplii" because of different biological features from those of adult copepods. Zooplankton identification was based on specific literature (Koste 1978, Streble \& Krauter 1987, Paggi 1995, Battistoni 1995, Bradford-Grieve et al. 1999). The differences among results of environmental variables were tested by analysis of variance (ANOVA, Statistica 7.0).

\section{RESULTS}

\section{Environmental variables}

During the period of study, rainfall in the lagoon region was higher as of mid-spring through mid-summer (November through February) but lower during autumn and winter months (Fig. 2). The lagoon water average temperature at both surface and bottom showed significant temporal differences $(\mathrm{p}<0.01)$, as a direct consequence of seasonal conditions, with higher temperatures typically related to summer time and lower tem-

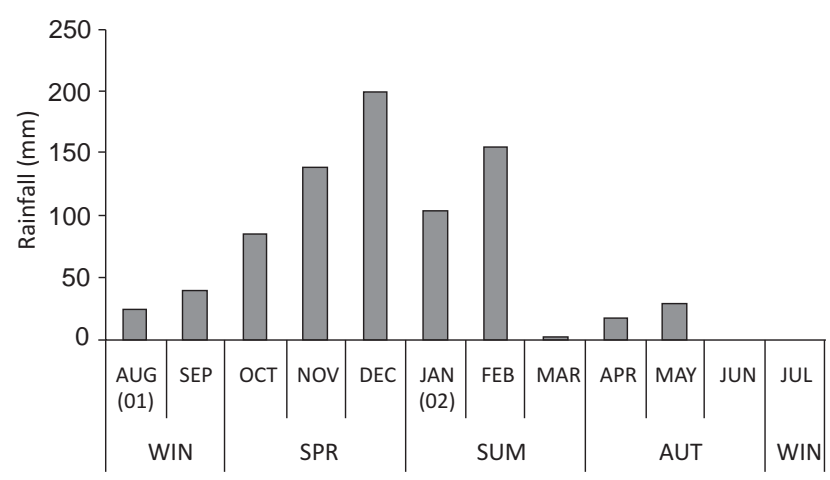

Figure 2. Monthly rainfall rates $(\mathrm{mm})$ in Rio de Janeiro, during the study period. Source: Instituto Nacional de Meteorologia. (WIN) Winter, (SPR) spring, (SUM) summer, (AUT) autumn. peratures during winter time (Fig. 3). Temporal salinity variations in Rodrigo de Freitas Lagoon were significant $(\mathrm{p}<0.01)$, and showed a continuous decline in values along the period of study (Fig. 4). Throughout the sampling period, the values of
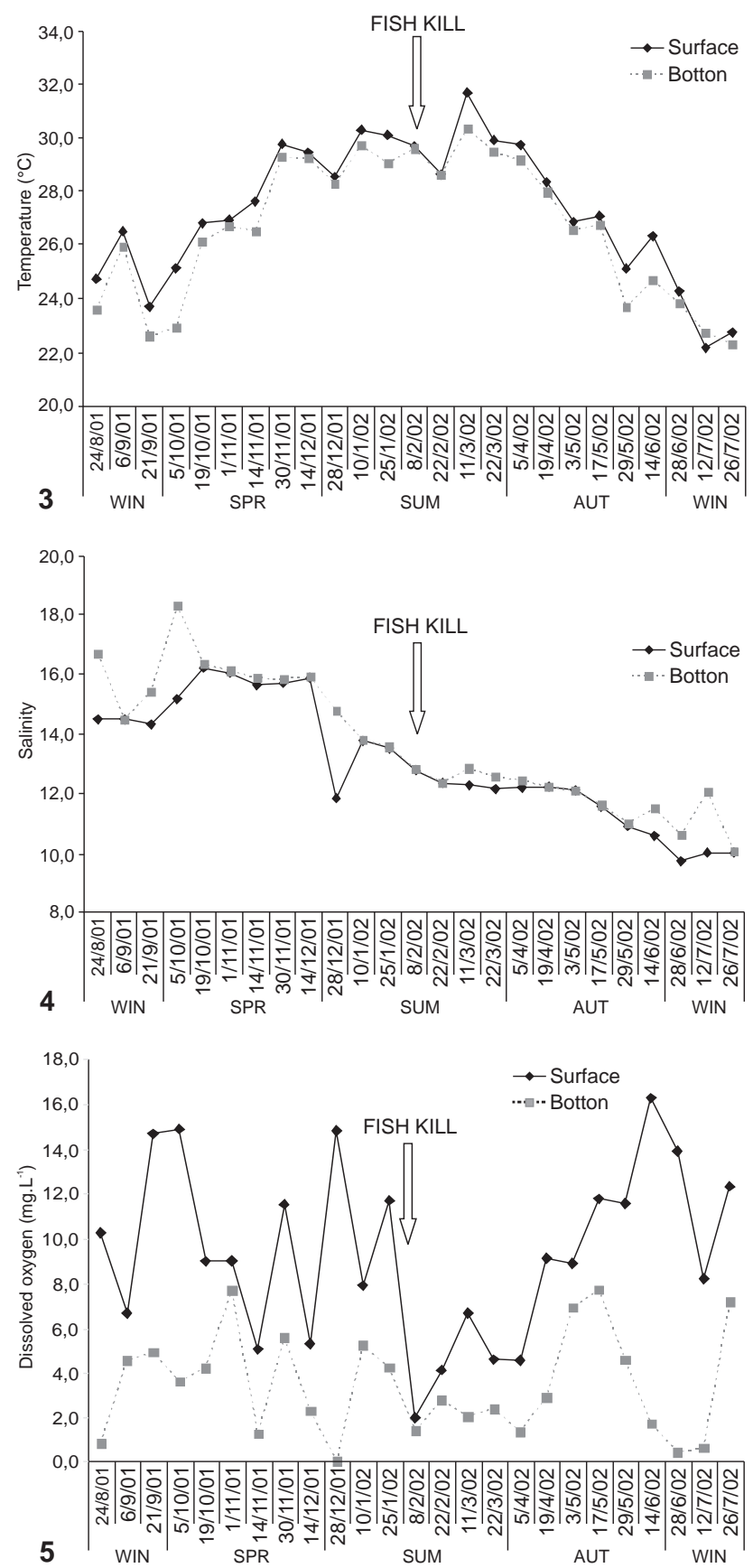

Figures 3-5. Temporal variation of average temperature (3), salinity (4), and DO (5) at the surface and at the bottom (August 2001 to July 2002). (WIN) Winter, (SPR) spring, (SUM) summer, (AUT) autumn. 
dissolved oxygen in the water, both at the surface and the bottom, showed high variability (Fig. 5) and significant differences between samples $(p<0.01)$. It should also be noted that for most samples, surface oxygen values did not show any positive correlation with the values at the lagoon bottom, pointing to a chemical stratification of the water column. Even with high temporal variability, dissolved oxygen values showed an overall downward trend during summer time. The lowest surface dissolved oxygen rate was recorded on the February $8^{\text {th }}$, 2002 sampling and corresponded to a fish kill period.

Rodrigo de Freitas Lagoon showed to be a spatially homogeneous environment according to environmental variables (Figs 6, 7 and 8). There were also no significant differences between surface and bottom in what regards salinity and water temperature (Figs 7 and 8). Nevertheless, at each point, the bottom dissolved oxygen value was lower than at surface, showing chemical stratification of the water column (Fig. 6).
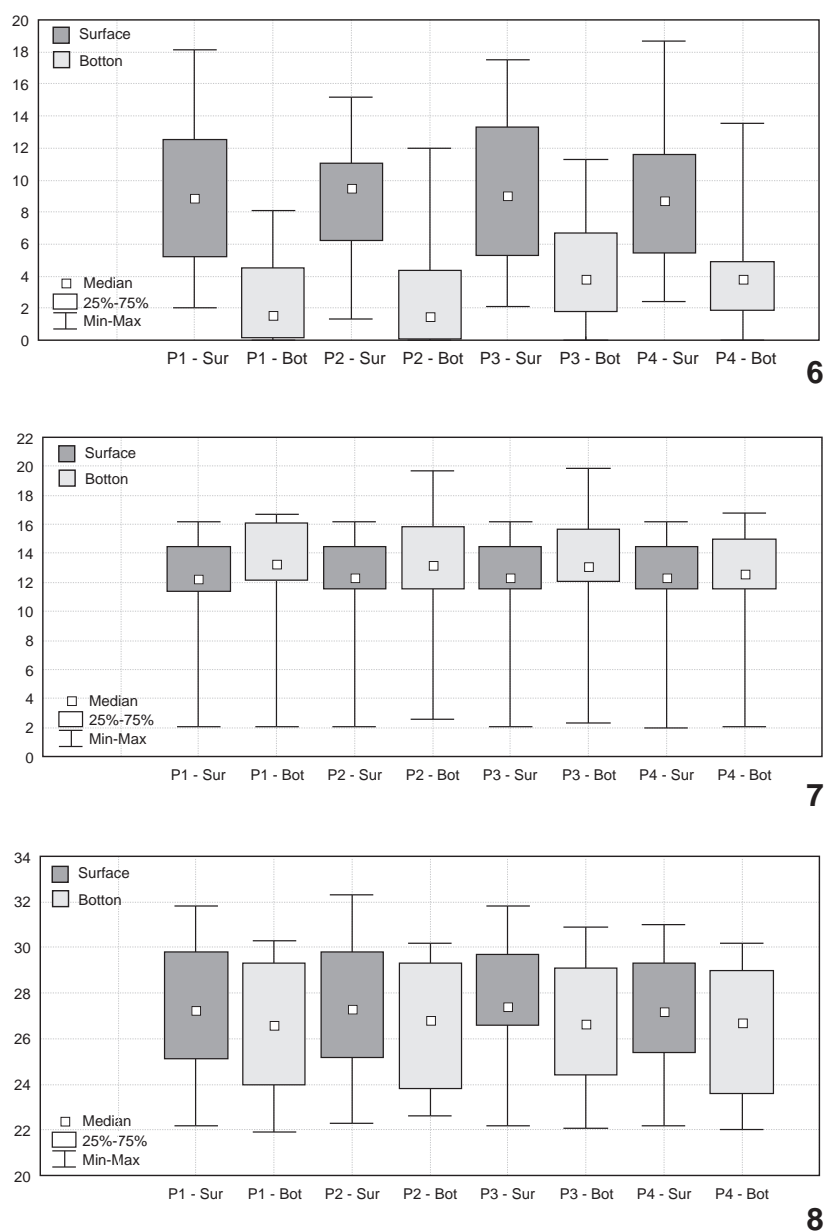

Figures 6-8. Dissolved oxygen (mg. $\left.\mathrm{L}^{-1}\right)(6)$, salinity (7) and water temperature $\left({ }^{\circ} \mathrm{C}\right)(8)$ values at the surface and at the bottom at sampling points $\mathrm{P} 1, \mathrm{P} 2, \mathrm{P} 3$ and $\mathrm{P} 4$.

\section{Zooplankton community}

Twenty-one taxa were identified along 12 months of sampling at Rodrigo de Freitas Lagoon (Tab. I). The rotifer Brachionus plicatilis O.F. Müller, 1786 (Brachionidae) was the highest frequency and density occurring taxon, as well as the most abundant in $44 \%$ of the samples.

Among the microcrustaceans, Calanoid copepod nauplii were present in all samples and dominant in terms of density in $28 \%$ of the samples. Acartia lilljeborgi Giesbrecht, 1892 (Acartiidae) and Acartia sp. were the major Calanoid copepods both in adult forms, copepodites, and probably, nauplii. A Peocilostomatoida copepod of the Oncaea genus (Oncaeidae) was also frequently found in the lagoon during the study as well as the ostracod Cyprinotus sp. Among the meroplankton found, cirripedia nauplius was the most abundant taxon. Although not abundant, gastropod larvae showed high frequency (64\%).

The total zooplankton density along the period of the study showed values lower than 200,000 individuals per cubic meter at all the sampling points until November 2001, but as of December, density increased until May 2002 (Fig. 9). Although the general density variation trend is similar at all sampling points, Point 2 tended to have higher values along the periods when there was higher zooplankton community abundance. This fact may be related to the more interior position of this point in the lagoon, probably a more convenient site for the $B$. plicatilis species, the one that accounts for the peaks in zooplankton density rates.

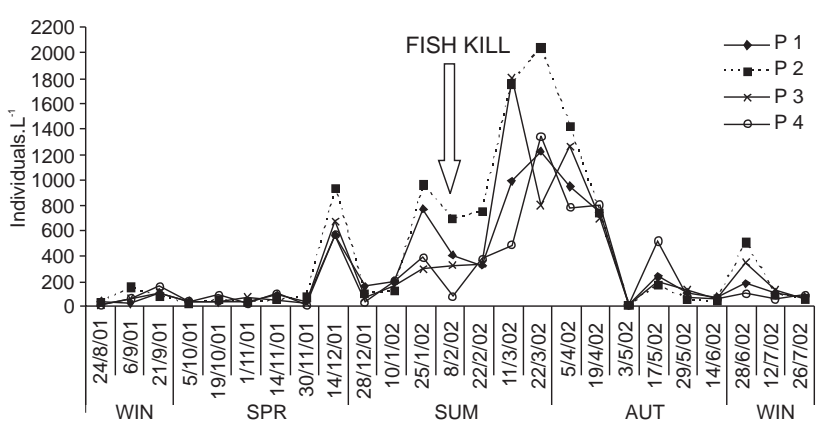

Figure 9. Temporal variation in total zooplankton density (individuals. $\mathrm{m}^{-3}$ ) detailed by sampling points. (WIN) Winter, (SPR) spring, (SUM) summer, (AUT) autumn.

Overall, the taxa that showed higher frequency are the same ones that show higher density (Fig. 10). An interesting fact was the increment in zooplankton abundance at all sampling points right after the sampling that followed fish death. Such increment is caused mainly by the B. plicatilis species. For all the March 2002 samplings its median density was higher than 1,100,000 individuals per cubic meter. It should be noted that in addition to B. plicatilis, copepod nauplii and cyrripediae, Cypronotus sp. and Oncaea sp. also showed increased abundance after the fish kill, during the months of February through April 2002. 


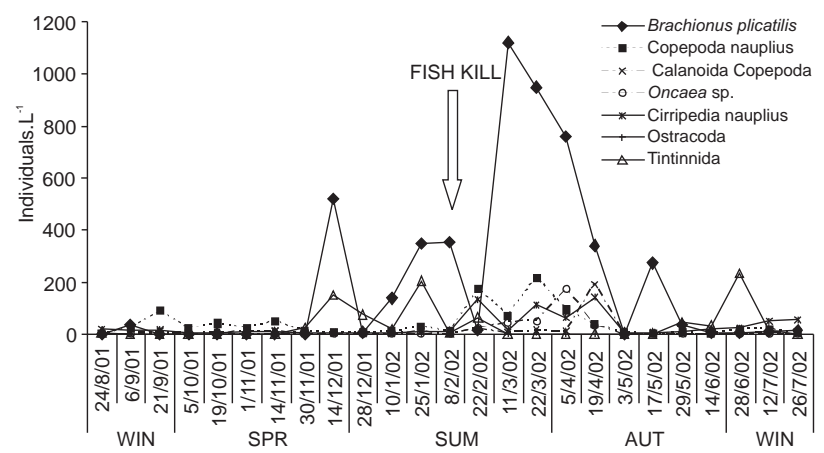

Figure 10. Temporal variation of density medians of the most frequently found taxa in Rodrigo de Freitas Lagoon. (WIN) Winter, (SPR) spring, (SUM) summer, (AUT) autumn.

\section{DISCUSSION}

\section{Environmental variables}

According to FEEMA's report (2002), the Jardim de Alah canal remained closed and/or silted for nearly all the period of this study, which resulted in a decline in salinity. As a consequence, Rodrigo de Freitas Lagoon had an average salinity value around 13 , and was considered mesohaline.
Values of dissolved oxygen in the water, both at the surface and the bottom, showed high variability, as previously reported by Gonzalez et al. (2006). Dissolved oxygen values showed an overall downward trend during summer time. The lowest surface dissolved oxygen rate $\left(2.0 \mathrm{mg} . \mathrm{L}^{-1}\right)$ was recorded on the February $8^{\text {th }}, 2002$ sampling and corresponded to a fish kill period, when 94 tons of fish were taken out of the lagoon.

Fish kills have been frequently reported in the lagoon since 1877. One of the largest fish kills was recorded in 1939, equivalent to about 300 tons of fish (Oliveira et al. 1957). There were 13 fish kills between March 1968 and May 1971, and others were registered in the summer of 1973 and 1974, all associated with low dissolved oxygen concentrations in the water column (FEEMA 2002).

The occurrence of fish kills in Rodrigo de Freitas Lagoon have been associated to three environmental conditions, the first of which has been already brought up by Oliveira et al. (1957) and is connected with a sharp fall in the air temperature that cools the water surface layer, and/or with strong winds that generate waves. Both associated events lead to a significant water column circulation that promotes re-suspension of bottom sediments and later organic matter oxidation, thus reducing the dissolved oxygen concentration in the water. The second environmental condition is the lack of lagoon-sea wa-

Table I. Abundance (individuals. $\mathrm{m}^{-3}$ ) and occurrence frequency (O.F.) of zooplanktonic taxa in Rodrigo de Freitas Lagoon.

\begin{tabular}{|c|c|c|c|c|c|}
\hline Taxa & Average & Maximum & Minimum & Standard deviation & O.F. (\%) \\
\hline \multicolumn{6}{|l|}{ Cilliophora } \\
\hline Tintinnid & 24,320 & 476,300 & 0 & 72,240 & 39 \\
\hline Cilliate I & 9,750 & 547,890 & 0 & 57,360 & 19 \\
\hline \multicolumn{6}{|l|}{ Rotifera } \\
\hline Brachionus plicatilis O.F. Müller, 1786 & 204,920 & $1,748,740$ & 0 & 359,980 & 88 \\
\hline Hexarthra sp. & 50 & 1,950 & 0 & 260 & 7 \\
\hline Keratella americana Carlin, 1943 & 10 & 320 & 0 & 40 & 11 \\
\hline Keratella cochlearis (Gosse, 1851) & 3 & 130 & 0 & 20 & 3 \\
\hline Lecane sp. & 0.47 & 30 & 0 & 3 & 2 \\
\hline Synchaeta sp. & 60 & 1,900 & 0 & 250 & 16 \\
\hline Bdelloidea & 10 & 430 & 0 & 60 & 9 \\
\hline \multicolumn{6}{|l|}{ Crustacea } \\
\hline $\begin{array}{l}\text { Calanoida Copepoda (Acartia lilljeborgi Giesbrecht } \\
\text { 1892, Acartia sp., Parvocalanus sp.) }\end{array}$ & 11,590 & 261,300 & 0 & 37,820 & 99 \\
\hline Harpacticoida Copepoda & 320 & 12,700 & 0 & 1,530 & 13 \\
\hline Copepoda nauplius & 39,390 & 311,690 & 160 & 60,600 & 100 \\
\hline Cirripedia nauplius & 29,600 & 209,380 & 760 & 43,610 & 100 \\
\hline Ostracoda (Cyprinotus sp.) & 930 & 24,660 & 0 & 3,320 & 46 \\
\hline Poecilostomatoidea (Oncaea sp.) & 13,020 & 207,770 & 0 & 38,230 & 27 \\
\hline \multicolumn{6}{|l|}{ Others } \\
\hline Acari & 4 & 40 & 0 & 4 & 1 \\
\hline Gastropod Larvae & 60 & 1,570 & 0 & 210 & 64 \\
\hline Polychaete Larvae & 170 & 1,420 & 0 & 240 & 27 \\
\hline Nematodes & 20 & 480 & 0 & 80 & 7 \\
\hline
\end{tabular}


ter exchange, which (i) accelerates the accumulation of organic matter under high water temperature and the consumption of dissolved oxygen; (ii) reinforces the activity of sulphate-reducing bacteria (SRB) and releases sulphidric gas $\left(\mathrm{H}_{2} \mathrm{~S}\right)$ to the water column; and (iii) increments adverse conditions to fish breathing and eventually causes their death. The third condition associated to fish kill in Rodrigo de Freitas Lagoon is related to the presence of toxin-producing phytoplankton species (OLIVEIRA et al. 1957), although this condition is not easily diagnosed.

The second condition mentioned above is what seems to have occurred during the February 2002 sampling, when the water temperature both at surface and at the bottom was high, the oxygen at surface was low and salinity was around 13. As mentioned before, salinity values were lower than those recorded at the beginning of the study, evidencing less exchange with the sea.

\section{Zooplankton community}

Salinity has been pointed as one of the main structuring forces of zooplankton communities in several tropical coastal lagoons. The existence of a direct connection of a lagoon with the sea or a permanent cut off seem to heavily impact the zooplankton community, as shown by KozLowsKY-SuZUKI \& BOzELLI (2004), Branco et al. (2007) and Santangelo et al. (2007) in Imboassica Lagoon (RJ). These studies concluded that if the connection with the sea was barred for a long time, the zooplankton community would be composed by freshwater organisms and would be more diverse. During those periods with open communication with the sea, the zooplankton would be composed mainly of marine organisms, and would also show a high number of taxa. Conversely, when communication with the sea was cut off recently in Imboassica Lagoon, in intermediary levels of salinity (mesohaline) zooplankton was composed by a reduced number of taxa, with one or a few species with high abundance.

In the present study, Rodrigo de Freitas Lagoon exhibited mesohaline conditions throughout the sampling period and the zooplankton showed a permanent low richness, generally with the predominance of only one taxon. This leads us to believe that the lagoon was probably in a condition analogous to those shown by Imboassica Lagoon in intermediary levels of salinity.

On the other hand, trophic interactions constitute one of the other driving factors acting on zooplankton community in coastal lagoons. Environments with the dominance of cyanobacteria, a common setting found in several coastal lagoons under human impact in the Rio de Janeiro State (Domingos et al. 1994), have unfavorable conditions to most zooplankton species (ArCIFA et al. 1994). In addition, the pressure suffered by zooplankton due to predation by other invertebrates and fish (BRANCo et al. 2008) is widely recognized. JePPESEn et al. (1994), when comparing freshwater and brackish water lagoons in temperate regions, concluded that the predation pressure on zooplankton was higher and algal grazing ca- pacity lower in brackish eutrophic-hypertrophic lakes than in comparable freshwater lakes.

It might be also suggested that low taxon richness levels in Rodrigo de Freitas Lagoon are related to the presence of a diverse and abundant fish community. ANDREATA et al. (2002, 2004) reported 63 fish species in the lagoon, 54 of which were marine and 9 were freshwater species. According to these authors, the lagoon plays a major role in marine life by attracting a large diversity of marine fish; however, the lagoon freshwater species do play an important role with respect to the total number of captured species.

The rotifer Brachionus plicatilis attained the highest frequency of occurrence and density. This species is considered euryhaline, can endure salinity levels ranging from 1 to 97 (ØIE \& Olsen 1993, Egborge 1994), and is typically a lagoon-occurring species (ARCIFA et al. 1994), being commonly found in coastal lagoons with varying salinity regimes in various parts of Brazil and the world (Neumann-Leitão et al. 1992, ArCiFa et al. 1994, EgBorge 1994). Both the higher occurrence and density of this species are indicative of mesohaline conditions in coastal lagoons (BRANCO et al. 2000, 2007). It should be noted that the presence of Brachionus plicatilis had been previously reported at Rodrigo de Freitas Lagoon in 1954 (Oliveira et al. 1957) and as plankton dominant in 1957 and 1958 (Oliveira et al. 1962). Two other rotifer species found by the present study, with low frequency and abundance, were Keratella americana and $K$. choclearis, both commonly-occurring in several Brazilian freshwater ecosystems, being the latter considered a cosmopolitan species.

In general, the most frequent taxa are also the most abundant, thus playing a major role in the total zooplankton. An interesting fact was the increment in zooplankton abundance at all sampling points right after a fish kill. Such increment was caused mainly by $B$. plicatilis species, whose density in March 2002 sampling was higher than 1,100,000 individuals per cubic meter. ArCIFA et al. (1994) studied the zooplankton community density variation in a coastal lagoon in Rio de Janeiro State (Barra Lagoon) and also observed a similar increment in zooplankton abundance after a fish kill. These authors also found that the increase in density resulted mainly from an increase in B. plicatilis species. The reported fish kill also occurred in February and zooplankton abundance remained higher up until late April.

Two conditions associated to the fish kill may have directly impacted the local zooplankton community: the decline in fish predation pressure and the shift in trophic conditions. The latter factor, although not assessed herein, was detected by Arcifa et al. (1994) at Barra Lagoon through changes in the phytoplankton community. According to the same authors, before the fish kill, the Barra Lagoon phytoplankton was composed predominantly of cyanobacteria, but after the fish kill by chlorophyceae, which are more palatable for zooplankton and which might explain the latter's increment in abundance. 
Besides B. plicatilis, copepod nauplii and cyrripedia, Cypronotus sp. and euryhaline Poecilostomatoidea copepod Oncaea sp. also showed increased abundance after the fish kill, during the months of February through April 2002. ArCIFA et al. (1994) also reported an increased abundance of one euryhaline cyclopoid copepod, Apocyclops procerus (Herbst 1955), and nauplii forms after the fish kill in Barra Lagoon, and associated that to the change in phytoplankton community.

Our study showed that the Rodrigo de Freitas Lagoon's zooplankton was composed mainly by taxa commonly found in coastal lagoons that undergo frequent variations in the seawater influx. Most of such organisms are euryhaline, some of which occur in both oligohaline and mesohaline lagoons, while others occur in estuaries and/or in coastal marine environments. Taxonomical richness was low when compared to other coastal lagoons in the Rio de Janeiro State. This is probably related to the influx of seawater and dissolved oxygen decline events causing fish kills, in addition to other biotic factors like phytoplankton availability and changes in fish predation pressure.

\section{ACKNOWLEDGEMENT}

We thank INEA for field assistance.

\section{REFERENCES}

Andreata, J.V. \& J.P. MendonçA-Neto. 2001. Aspectos reprodutivos de Poecilia vivipara (Bloch \& Schneider) (Poeciliidae da Lagoa Rodrigo de Freitas, Rio de Janeiro, Brasil. Revista Brasileira de Zoologia 18 (4): 1041-1047.

Andreata, J.V.; F.V. Manzano; M.G.S. Baptista; D.E. Teixeira; L.O.V. Oliveira; M.M. Longo; N.V. Freret \& A. S. Valois. 2002. Assembléia de peixes da Lagoa Rodrigo de Freitas, Rio de Janeiro. Acta Biologica Leopoldensia 16: 19-28.

Andreata, J.V.; L.O.V. Oliveira; B.C. Meurer; N.V. Freret; D.E. Teixeira; F.V. Manzano \& M. M. Longo. 2004. Peixes pelágicos da Lagoa Rodrigo de Freitas, Rio de Janeiro, Brasil. Revista Estudos de Biologia 26 (55): 25-31.

Aragão, H.R.; J.C. Penido; M.F. Santos \& L.P.H. Oliveira. 1939. Relatório sobre a situação da Lagoa Rodrigo de Freitas sob o ponto de vista biológico. Memórias do Instituto Oswaldo Cruz 34 (4): 457-463.

Arcifa, M.S.; M.S.M. Castilho \& J.P. Carmouze. 1994. Composition et évolution du zooplankton dans une laguna trpocale (Brésil) au cours d'une période marquée par une mortalité de poissons. Revue d' Hydrobiologie tropical 27(3): 251-263.

Attayde, J.L. \& R.L. Bozelli. 1998. Assessing the indicator properties of zooplankton assemblage to disturbance gradients by canonical correspondence analysis. Canadian Journal of Fisheries and Aquatic Sciences 55: 1789-1797.

BARNES, R.S.K. 1980. Coastal lagoons - The natural history of a neglected habitat. Cambridge University Press, 105p.

Battistoni, P.A. 1995. Crustacea Copepoda, p. 953-971. In: E.C.
Lopretto \& G. TelL (Eds). Ecosystemas de aguas continentales - Metodologias para su studio. La Plata, Ediciones Sur. Tomo III, $1401 \mathrm{p}$.

Berzins, B. \& B. PejLer. 1987. Rotifer occurrence in relation to pH. Hydrobiologia 147: 107-116.

Bradford-Grieve, J.M.; E.L. Markhaseva; C.E.F. Rocha \& B. Abiahy. 1999. Copepoda, p. 869-1098. In: Boltovskoy, D (Eds). South Atlantic Zooplankton. Leiden, Backhuys Publishers, vol. 2, $1705 p$.

Branco, C.W.C; B. Kozlowsky-Suzuki; F.A. Esteves \& L.C. Souza. 2000. Rotifers as ecological indicators in three coastal lagoons in the State of Rio de Janeiro, p. 429-448. In: Anais do V Simpósio de Ecossistemas Brasileiros: Conservação. Vitória, Universidade Federal do Espírito Santo, vol. 2.

Branco, C.W.C; B. Kozlowsky-Suzuki \& F.A. Esteves. 2007. Environmental changes and zooplankton temporal and spatial distribution in a disturbed Brazilian coastal lagoon. Brazilian Journal of Biology 67 (2): 251-262.

Branco, C.W.C; B. Kozlowsky-Suzuki; F.A. Esteves \& T. Aguiaro. 2008. Zooplankton distribution and community structure in a Brazilian coastal lagoon. Vie et Milieu - life and environment 58 (1): 1-9.

Domingos, P.; V.L. Huszar \& J.P. Carmouze. 1994. Composition et biomasse de phytoplancton d'une lagune tropical (Brèzil) marqué par une mortalité de poisson. Revue Hidrobiologue Tropical 27 (3): 235-250.

Egrorge, A.B.M. 1994. Salinity and the distribution of rotifers in the Lagos Harbour-Badagry Creek system, Nigeria. Hydrobiologia 272: 95-104.

FEEMA. 2002. Qualidade da água da Lagoa Rodrigo de Freitas. Rio de Janeiro, Fundação Estadual de Engenharia do Meio ambiente, Relatório Técnico, 44p.

Gonzalez, A.S.M.; R. Paranhos \& M.S. Lutterbach. 2006. Heterotrophic bactéria abundances in Rodrigo de Freitas Lagoon (Rio de Janeiro, Brazil). Brazilian Journal of Microbiology 37: 428-433.

Jeppesen, E.; M. Søndergaard; E. Kanstrup; B. Petersen; R.B. Eriksen; M. Hammershøj ; E. Mortesen; J.P. Jensen \& A. Have. 1994. Does the impact of nutrients on the biological structure and function of brackish and freshwater lakes differ? Hydrobiologia 275/ 276: 15-30.

KJERFve, B. 1994. Coastal lagoons, p. 1-8. In: B. KJerfve (Ed.). Coastal lagoon processes. Amsterdam, Elsevier Oceanography Series, $60,577 \mathrm{p}$.

Kozlowsky-Suzuki, B. \& R.L. Bozelli. 2002. Experimental evidence of the effect of nutrients enrichment on the zooplankton in a Brazilian coastal lagoon. Brazilian Journal of Biology 62 (4b): 835-856.

Kozlowsky-Suzuki, B. \& R.L. Bozelli. 2004. Resilience of a zooplankton community subjected to marine intrusion in a tropical coastal lagoon. Hydrobiologia 522: 165-177.

Koste, W. 1978. Rotatoria. Die Rädertiere Mitteleuropas. II Tafelband. Berlin, Gebrüder Borntraeger, 234 p. 
KuCZYNSKI, D. 1987. The rotifer fauna of Argentine Patagonia as a potential limnological indicator. Hydrobiologia 150: 3-10.

Lutterbach, M.T.S.; J.C. VazQuez; J.A. Pinet; J.V. Andreata \& A.C. SILVA. 2001. Monitoring and spatial distribuition of heterotrophic bacteria and fecal coliforms in the Rodrigo de Freitas Lagoon, Rio de Janeiro, Brasil. Arquivos de Biologia e Tecnologia 44 (1): 7-13.

Neumann-Leitão, S.; M.N. Paranaguá \& J.L. Valentin.1992. The planktonic rotifers of the estuarine lagunar complex of Suape (Pernambuco, Brazil). Hydrobiologia 232: 132-143

ØIE, G. \& Y. OLSEN. 1993. Influence of rapid changes in salinity and temperatura on the mobility of the rotifer Brachionus plicatilis. Hydrobiologia 255/256: 81-86.

Oliveira, L. 1955. Sobre a lei da concentração das lagunas e sua aplicação no caso da Lagoa Rodrigo de Freitas. Memórias do Instituto Oswaldo Cruz 53 (2-4): 263-276.

Oliveira, L.; R. Nascimento; L. Krau \& A. Miranda. 1957. Obser- vações hidrobiológicas e mortandade de peixes na Lagoa Rodrigo de Freitas. Memórias do Instituto Oswaldo Cruz 55 (2): 219-248.

Oliveira, L.; R. Nascimento; L. Krau \& A. Miranda. 1962. Observações ecológicas sobre Brachionus plicatilis Mueller em águas tropicais salobras e mesosapróbicas (Rotatoria). Memórias do Instituto Oswaldo Cruz 60 (2): 155-163.

PagGi, S.J. 1995. Rotifera, p. 643-667. In: E.C. Lopretto \& G. TelL (Eds). Ecosistemas de aguas continentales - metodologias para su estudio. La Plata, Ediciones Sur, Tomo II, 895p.

Santangelo, J.M.; A.M. Rocha; R.L.Bozelli; L.S. Carneiro \& F.A. Esteves. 2007. Zooplankton responses to sandbar opening in a tropical eutrophic coastal lagoon. Estuarine Coastal and Shelf Science 71: 657-668.

Streble, H. \& D. Krauter. 1987. Atlas de los Microinvertebrados de agua dulce. La vida en una gota de agua. Barcelona, Ed. Omega, 340p.

Submitted: 08.X.2010; Accepted: 20.III.2011.

Editorial responsibility: Paulo da C. Lana

ZOOLOGIA 28 (3): 357-364, June, 2011 